\title{
NATIONALISM ON THE INTERNET: A DISCURSIVE ANALYSIS OF THE TURKISH CASE
}

\author{
SERCAN GIDIŞOĞLU* \\ BoğaziçiUniversity
}

\author{
KEREM RIZVANOĞLU** \\ Galatasaray University
}

\begin{abstract}
The main aim of this research is to capture a comprehensive picture of the overtly Turkish nationalist sites that define themselves as nationalist on the Internet and to demonstrate their extent as well as different appearances. Therefore, this research aims to answer first, what role the Internet is playing on the formation and reproduction of collective identity and community for nationalist groups; and second, in doing that, what kind of content is presented in nationalistic web sites through which tools and visual layout design aspects. The study attempts to provide a qualitative discursive analysis of Turkish nationalist web sites through the main features they present. A total of 118 web sites are included in the analysis. The study proposes a concrete typology of the network structure of online Turkish nationalism. It also concludes that Turkish nationalists mainly use the Internet in order to diffuse their ideology, to strengthen Turkish national identity and nationalist community structure and finally to build a dedicated virtual community. In order to realize this purpose, Turkish nationalists benefit from various content categories. Findings also reveal that the visual layouts of the web sites provide opportunities for the reconstruction of a manipulated interaction oriented around the imposed nationalist ideology.
\end{abstract}

Keywords: nationalism, Turkish Nationalism, Internet, discourse, content, design.

\section{INTERNETTE MILLIYETÇILIK: TÜRKIYYE ÖRNEĞİNIN SÖYLEMSEL ANALIZI}

\section{ÖZET}

Bu araştırmanın amacı, internet üzerinde kendisini açıkça milliyetçi olarak tanımlayan Türk milliyetçi sitelerinin hem içerik hem de biçim düzeyinde bütünlüklü bir resmini sunmaktır. Bu anlamda araştırma, öncelikle milliyetçi gruplar için kollektif kimliğin ve topluluğun oluşumunda ve yeniden üretiminde internetin rolünü ortaya koymayı amaçlamaktadır. Buna ek olarak söz konusu süreçte millliyetçi sitelerde sunulan içeriğin mahiyeti ve bu içeriğ in hangi araçlar ve görsel tasarım elemanları aracıllğgyla sunulduğu incelenmektedir. Çalışma, sundukları unsurlar üzerinden Türk milliyetçi sitelerinin niteliksel bir söylemsel analizini içermektedir. Analiz kapsamında 118 web sitesi yeralmaktadır. Çalışmanın

* Sercan Gidişoğlu is a Ph.D. candidate in the Department of Political Science and International Relations at Boğaziçi University, 34342, Bebek, Istanbul, Turkey. E-mail: sercan.gidisoglu@gmail.com

** Kerem Rızvanoğlu is an Associate Professor in the Faculty of Communications at Galatasaray University, Çırağan Caddesi, No:36, 34357, Ortaköy, Istanbul, Turkey. E-mail: krizvanoglu@gsu.edu.tr 
bulguları öncelikle çevrimiçi Türk milliyetçiliğinin a ğ yapısının tipolojisini sunmaktadır. Buna ek olarak çalışma, Türk milliyetçilerinin interneti idelolojilerini yaygınlaştırmak, Türk milliyetçi kimliğini ve milliyetçi topluluk yapısını güçlendirmek ve son olarak birbirine bağlı bir sanal topluluk oluşturmak için kullandı ̆̆ını ortaya koymaktadır. Bu amacı gerçekleştirmek için farklı içerik kategorileri kullanılmaktadır. Bulgular, web sitelerinin görsel tasarımlarının da empoze edilen milliyetçi ideoloji etrafinda düzenlenen yönlendirilmiş bir etkileşimin inşası için olanaklar sunduğunu göstermektedir.

Anahtar kelimeler: milliyetçilik, Türk Milliyetçiliği, İnternet, söylem, içerik, tasarım.

The Internet has become one of the major venues of the modern world in which virtual and real actors anonymously or explicitly interact. Although being a virtual venue, it theoretically presents unlimited global access independent of time and space, making it especially attractive to all kinds of groups that aim to reach mass populations. Therefore, nationalists or extremists all around the world try to use the Internet to realize their purposes. The subject of this study is the examination of the Turkish nationalist web sites on the Internet. The main aim of this research is to capture a comprehensive picture of the overtly nationalist sites that define themselves as nationalist on the Internet and to demonstrate their extent as well as their different appearances. Therefore, this research will try to answer first, what role the Internet is playing on the formation and reproduction of collective identity and community for nationalist groups; and second, in doing that, what kind of content is presented in nationalistic web sites through which tools and visual layout design aspects. It is hypothesized that through the use of specific content categories and tools, the Internet serves to reproduce nationalist discourses and values, thus strengthening national allegiances. Finally, it is assumed that the design of these web sites is manipulated in such a way as to facilitate this purpose.

A significant number of articles emphasizing the democratic and deliberative enhancing capacities of the Web have been published during the last decade (see Anderson et al., 2003; Dalhgren, 2000 and 2005; Quintelier and Vissers, 2008; Tambini, 1999; Tian and Wu, 2007). In this context, studying the nationalist sites might be particularly important in demonstrating that the Internet does not solely and automatically serve to promote deliberation, democracy and unity in a given society. Studying nationalism in the Turkish context is also significant because nationalism has been the predominant and hegemonic ideology for a long time in Turkish political culture; it may even be claimed to be the most dominant ideology throughout the political history of the Turkish Republic. There is an ample literature on Diaspora nationalisms on the Internet, but nationalistic discourses coming from groups belonging to the host nation and their content as well as social functions constitute a scholarly untapped area of study despite their great importance. In addition, this study can be defined as the first attempt to construct a typology of Turkish cyber-nationalism and to present an in-depth overview of Turkish nationalist web sites. As another original contribution to relevant literature, this study also tries to combine a political science perspective with that of new media studies. Departing from a typology of Turkish nationalist web sites derived from an in-depth analysis of the network structure of Turkish cyber-nationalism, this study aims to present findings through a qualitative content analysis of Turkish nationalist web sites in correlation with the functions (tools) presented in them. In addition, the aspect of the design of visual layout will be briefly examined.

This paper focuses on Turkish nationalist web sites as a virtual public sphere, and aims to analyze the mechanisms through which nationalism as a discourse is produced and reproduced by its participants. Therefore, it chooses deliberately a sample composed primarily of web sites that call themselves 
nationalistic and leaves aside other popular common web sites such as Facebook or Twitter or the sites that are either implicitly or covertly nationalistic. Regarding the time issue, it should be noted that it is very difficult to measure the change in these sites over time due to the very fast changing and growing nature of the net. Nevertheless, it is observed that the essential content in these sites, ideological and rhetorical, does not change a lot over time. It is only the contextual elements that occur for short periods depending on the political context; they then disappear but the main rhetorical constituents remain in place. In the first place, the relevant literature about nationalism on the Internet including hate sites and extremist groups will be reviewed. Secondly, methodological issues such as the frame of analysis as well as sampling and analyzing methods will be mentioned. Then a typology of Turkish cybernationalism will be offered before concluding with their presentation and a discussion of the results.

\section{NATIONALISM AND/ON THE INTERNET}

Many important researchers assume throughout almost all their scholarly work that we are living in a global information society and that it is worth noting that the Internet has become one of the leading elements of it. As the Internet has no physical territory, one of its defining features is that it is place dissolving and place generating; it is de-territorialized and de-territorializing at the same time (Diamandaki, 2003, italics original). Hence, digital nations and virtual ethnicities are "novel mediated localities; non-geographical yet communicatively integrated social spaces, which give meaning to their inhabitants" (Diamandaki, 2003: 14). Unlike offline nationalisms, it is more difficult for online nationalisms to be territorially identified. Therefore, in order to better comprehend the nature of online nationalism it might be more useful to employ Anderson's (1983) conception of "structural (and nongeographical or historical) nationalism" (in Diamandaki's terms, 2003, parenthesis in original) which conceives nations and nationalisms as imagined communities. It will not be wrong to assume that the public sphere is migrating from the bounded, geographical territorialities of the past to the diffuse and immaterial networks of communication and media flows (Diamandaki, 2003: 6).

We can mention two main approaches regarding the relation between the Internet and nationalism: the global village idea which assumes primarily that the Internet serves to undermine the importance of national allegiances in favor of a more globalized identity vs. the approach claiming that the Internet is used to strengthen national identities. This second approach is mostly referred in the literature as the dark side of the Internet. This second approach illustrating the dark side claims that the Internet is used as a vehicle to strengthen national identity and to organize nationalist groups within different territories (Bakker, 2001; Diamandaki, 2003; Eriksen, 2007; Miller and Slater, 2000). One very striking finding among recent research on the Internet use demonstrates that the Internet can be very efficient in reproducing national identities in order to unite dispersed communities across vast distances; thus it strengthens rather than weakens national identities (Miller and Slater, 2000). According to Piet Bakker (2001), unlike the idea that the Internet weakens nation-states and we are heading towards a global village, nationalism is flourishing; the most important sign of this new nationalism is the spread of online activities. In addition, Diamandaki (2003) supposes that virtual ethnicities constitute counterarguments for the global village thesis, and, contrary to what is supposed by this latter, the Internet opens up new spaces for identity discourse. Accordingly, the same features (the global scope, relatively low cost and decentralized openness of the medium) that seem to undermine national identity - as argued by global village theorists - also serve to reproduce or even strengthen it. Along the same line of reasoning, Eriksen concludes that with the spread of information and communication technologies, notably of the Internet, nationalism is becoming stronger and that, especially, diasporic nationalisms are those most expressed on the Internet. 
The biggest contribution in terms of volume stems from the studies of diasporic (including also ethnic and separatist) nationalisms, especially in the Chinese case (see. Anyefru, 2008; Chan, 2005; Gladney, 2005; Liu, 2006) but also in other diasporic communities (Curtis, 2005; Eriksen, 2007; McLelland, 2008; Parker and Song, 2006; Rızvanoğlu and Güney, 2009; Shanadi, 2007; Uimonen, 2001). The main reason behind the fact that diasporic communities so often become subjects of scholarly attention might be found in their ceaseless attempts to create an image of the homeland as against their respective host societies and either to make their voice heard by these latter or simply to create a visual sharing center of common identities. This makes them quite visible and active on the net. The main idea presented by the quasi-totality of this Diaspora literature contains the argument that nationalist identities are reproduced and strengthened by Diasporas through the Internet. Eriksen (2007) does not prefer to make a distinction that is labeled as either diasporic or non-diasporic nationalisms; rather he describes four types of Internet nationalism: (1) state-supported (Chile), (2) surrogate (Afrikaner), (3) pre-independence (Kurdish), (4) multiculturalist (Moroccan-Dutch). A fifth type can be exemplified as oppositional, with the example of the expatriate Laotians' movement against their government in which they used their own language (Uimonen, 2001).

Liu (2006) describes an additional type as 'cyber-nationalism' with the example of China's popular nationalism on the Internet. The cyber-nationalism, Liu argues, "not only challenges the state monopoly over domestic nationalist discursive production, but also opens up new possibilities for using the people's "public discursive right"' (Liu, 2006: 1). Another attempt at categorization comes from Diamandaki (2003) who classifies online communities under two categories, namely diasporic and non-diasporic, and their sub-categories. Accordingly, diasporic communities involve nations or national groups without a State, expatriate/immigrant communities of existing Nation-States and finally communities of dissidents who have fled totalitarian regimes. In contrast, non-diasporic communities are composed of nations with a State, regional ethnicities within a Nation, and lastly marginalized or threatened identities of indigenous and tribal populations. Our sample corresponds exactly to the first branch of the second category mentioned here, namely non-diasporic communities belonging to the sub-group of "nations with a State." Diamandaki observes that this type of web sites transmits messages of self-assertion and of hate for the national 'Others' or gratification of the national or racial 'Us.' Our data from the Turkish case is also consistent with this observation. "Turkish nationalism on the Internet deepens along the lines of hostility of the 'Others'” (Güngör, 2007: 5).

Besides nationalist - either diasporic or non-diasporic - web sites, there is also a rich literature on the Internet usage of hate groups or extremists such as racists and neo-Nazis as well as other extreme-right or left organizations. As phrased by Donelan (2004: 22); "hate now has a new and powerful way to get into our homes...the Internet." Studying the hate sites on a world wide scale, Gerstenfeld et al. (2003: 32) listed them under ten categories depending on the nature of the message conveyed; Ku Klux Klan, Militia, Skinhead, Neo-Nazi, Christian Identity, Posse Comitatus, Holocaust Denial, White Nationalist, Other, None. Constructing a network of extremists - both on national and international scales - through linking with other extremists appears to be a very important preoccupation for these web sites. Hence, through a social network analysis Burris, Smith and Strahm (2000) found evidence that the Internet helps extremist groups build an international virtual extremist community (over two thirds of the links are to international sites). Another curious characteristic of these groups appearing in Gerstenfeld et al.'s research is the infrequent overt support of violence and fairly frequent claims that those groups were unbiased, not racist, and not hate groups. Meanwhile, most of the time nationalists do not hesitate proudly to cite their ideology on the net. 
While analyzing the racism on the web, Rajagopal and Bojin (2002) broadly detected five types of hate messages: civilized messages, humorous and light-hearted quips, simple and persuasive appeals, claims of self-preservation, and product advertisement. The respective corresponding rhetorical forms these messages take are educational narrative, stealth images and dialogue, coded metaphor, survival discourse, and marketing rhetoric. Regarding the racist content on the net, Lynn Thiesmeyer (1999) underscores some main features of these web sites such as constant self-definition, identification of various threats, enemies and conspiracy theories, emphasis on a collapsed order, etc. She also adds that many features of quite old rituals are repeated in the forum pages of these sites, including constant repetition, group solidarity, use of arbitrary symbols, the threat of punishment, verbal fetishization of violent and sacrificial death, highly subjective interpretive methods that reject opposition a priori, and hieratic visual and verbal discourse (idem: 118). Both studies reveal that, in nationalist websites, it is very difficult to separate the content from online rhetoric since there is a mutual relationship between them. Content is defined by the rhetoric.

Recently, a research similar to ours was conducted by Caiani and Parenti (2009) concerning the case of Italian right-wing extremist web sites. They employed a social network analysis of web linkage among approximately 100 organizations combined with a formalized content analysis. They argued that there was an increase not only in the number of right-wing organizations present on the net but also in their usage of the Internet for several different purposes such as "diffusing propaganda, promoting 'virtual communities' of debate, fundraising, and organizing and mobilizing political campaigns" (Caiani and Parenti 2009: 273). Similarly, Caiani and Wigemann (2009) examined, with a comparative perspective and through a social network analysis, the right-wing nationalist networks including political parties and non-party organizations in Italy and Germany. They asserted that the Italian network appeared to be more fragmented, highly diversified, and difficult to be coordinated ('policephalous network') whereas the German one was denser and much more concentrated on a few central actors ('star structure'). Beside the differences mainly due to political opportunity structures in the two countries, Caiani and Wigemann (2009: 66) suggested as a common conclusion that "extremist groups increasingly use and abuse the Internet for their propaganda and their recruitment, and also for their internal communication."

The research about nationalists and extremists on the Web shows that the Internet is used by those groups for several different purposes such as disseminating propaganda and inciting violence (Caiani and Parenti, 2009; Glaser et al., 2002), enhancing political consensus-seeking (Hoffman, 1996), spreading hateful messages (Barnett, 2007), facilitating recruitment (Zhou et al., 2005), generating collective identities (Thiesmeyer, 1999) and pride (Barnett, 2007), helping mobilization (Parker and Song, 2006; Caiani and Parenti, 2009), marketing purposes including fundraising, reaching a mass audience, entertaining and recruiting new followers (Conway, 2006; Rajagopal and Bojin, 2002; Weimann, 2006) and most importantly community building online (Caiani and Parenti, 2009; Diamandaki, 2003; Tateo, 2005; Thiesmeyer, 1999). For realizing these purposes, nationalists employed a variety of online rhetoric. Many of the arguments repeated by these groups are already mentioned in the review. The content analysis in this research is also framed by using some categories offered by the literature. Most of the categories that we preferred to use stems from the work of Lynn Thiesmeyer. Thiesmeyer (1999: 120) proposes seven categories for analyzing the content of the online rhetoric used in racist web sites: (1) pedantism, (2) urgency, (3) the use of 'historicism,' fake tradition and folk etymology, (4) de-legitimization of other discourses, (5) overt and privileged use of a 'collective subjectivism' ('virtual community' vs. 'real' community), (6) dual structure of the production side (composed of ideology makers and agents), and (7) factualization. We will explain how we used and modified this structure in the following section. 
Community-building online, involving notably collective subjectivity and identity formation is believed to be the most important purpose for which the Internet is manipulated by Turkish nationalists. Therefore, we will especially attempt to deepen our understanding about this feature. As suggested by Diamandaki (2003: 1), the ambiguous and complex environment of the Internet constitutes a new arena for the expression of the demands for recognition, generating hybrid collective formations such as digital nations, virtual diasporas and other online communities of an ethnic/national orientation. What allows for the reconstruction of these communities in the case of computer-mediated-communication is the flexibility and openness of the Internet. Ironically, the Internet - a placeless medium - allows for the (re)creation of place. Consequently, this newly created place, namely the online community, works as a symbolic glue that can gather and hold people together, as a mechanism for gaining visibility in the public sphere, and notably as a medium for constructing identity and collective subjectivities (Diamandaki, 2003). Nevertheless, it should also be noted as a limitation that any constructed digital nation is subject to the ephemerality that stems from the a-temporal, non-durable and constantly changing nature of cyber-discourse (Diamandaki, 2003).

In contrast to the reviewed literature, our study also deals with the aspect of design. Regarding the role of design in nationalist web sites, we were able to find only one directly related recent article, published in 2007 by Wright and Street, which in its turn underlines strongly the lack of literature about this issue. Thus, the arguments presented in this part about the role of design will be mainly taken from Wright and Street's work. They argue that what will determine the nature of participation through the Internet, whether it will be a deliberative action or an act to strengthen nationalistic discourses, is not only the content of discussions in forums but also the way these sites are designed and the discussions are organized. In addition, Barnett (2007) analyzes the visual content of US hate sites. He found that extremists take full advantage of the visual communication capabilities presented by the Internet in order to support their community-building efforts. Following their case study, Wright and Street (2007) conclude that design does not determine deliberation but it can facilitate or impede it. The processes by which web sites are commissioned and the parameters that are designed into the software should be studied carefully if we are to understand the nature of the deliberation on the net. Wright and Street (2007: 12) believe that this would help us "to move beyond the rather sterile debate that tends to dominate the stand-off between those who believe that the internet can enhance deliberation, and those who believe it will harm it." After examining the EU and UK online discussion forums, they argued that the potential importance of design is not limited to the architecture of the Internet itself but to the nature of the interface: how it is designed and constructed (Wright and Street 2007: 17). Wright and Street conducted a very useful study, but they did not however attempt to combine the design aspect with an analysis of the content or discourse presented by nationalists on the net. Therefore, we believe that our study might make a modest contribution to the literature on that point.

\section{TURKISH NATIONALISM}

Regarding the Turkish example, scholars generally employ two competing interpretations - namely the modernist and the ethno-symbolist - for explaining the nature of Turkish nationalism and notably the nation-building process in modern Turkey. According to Gol (2005), modernist explanations are more appropriate to understanding the Turkish nationalism which is causally linked to the Ottoman modernization process and is founded on an image of a modern nation with territorial sovereignty after the erosion of the traditional Ottoman umma (religious community) identity and the relevant millet system. Hence, the ethnic element was less significant because of the fact that Islam became the stronger social force unifying Turks and Kurds within the same boundaries during the construction 
of the nation. Gol also suggests (2005: 121) that "the ontology of otherness becomes the necessary basis of social imagination" of a nation. He uses as an example the Armenians, whose claims over the Anatolian territory were taken as a real threat to Turkish identity as well as the territorial basis of the nation, thus constituting the first 'Others' during the nation-building process. In the current offline Turkish nationalism, Armenians and Kurds are considered as the principal 'Others;' however, on the cyber network Kurds are seemingly the first and most excluded 'Others.'

Meanwhile, Canefe (2002: 150) claims that "the modernist core of the Turkish National Revolution needs to be re-examined in terms of its relation with older myths, acceptances and traditions that influenced the Ottoman/Turkish socio-cultural realm." She underlines a particular tradition of patriotism and communalism bordering nationalism in the modernization period of Ottoman Empire and suggests that (idem: 145) this tradition - built upon a reasonable mass of indigenous material and sentiments - led to the formation of an idiom and movement of patriotic Turkish nationalism, notably after some determinant historical events such as the separatist and independentist movements of some ethnic groups in the Empire, the Balkan Wars and finally the Turkish Independence War. She thus concludes that the ethno-symbolic model helps us better capture the relation between the two highly antagonistic but co-existing sets of historical, cultural and political traditions stemming from imperial Ottoman and Turkish national history.

In a very recent contribution to this debate and through the analysis of the Turkish schoolbooks and curricula, Keyman and Kancı (2011) argue that the ethno-centric and civic-political interpretations of citizenship have simultaneously co-existed and have gone through repeatedly occurring swings. The concept of territoriality took precedence over other factors during the creation of the new state in 1923. Afterwards, the territorial factor has been completed with the ethnic conceptualizations of the nation, and both dimensions - civic and ethnic - became the underlining elements of the discourse of official Turkish nationalism. Our analyses show that Turkish cyber-nationalists, despite emphasizing often the essential place of the territorial element, constitute a clear example of ethnic nationalism that validates only one dominant ethnic group (the Turks in the sense of Anthony Smith's 'ethnic core' or 'dominant ethnic') and leaves no room for other ethnic groups within the Turkish nation. However, the political parties especially, with a preoccupation of 'image control' (Gerstenfeld et al., 2003), attempt not to openly support an ethnic type of nationalism, but rather claim to be civic nationalists who also emphasize notions like citizenship, rights and duties, legal institutions of the Republic, etc. Nevertheless, Turkishness, the unity of Turkish territory and the indivisibility of the nation, are dealt with above all other constituting factors in their websites. They can only accept the existence of other ethnic groups within the Turkish nation as long as these latter identify themselves as a part of the Turkish nation or 'accept the "irreversible truth" that they are in reality Turks any way' (as often suggested by the documents in informative links of nationalist websites).

\section{Analysis Framework}

The first section of the analysis framework includes the investigation of the network structure of Turkish nationalism and the proposition of a concrete typology. The remainder of the analysis framework is derived from the main aspects of nationalist and racist web sites mentioned in the literature review. Accordingly, in this second section, which focuses solely on the web sites, our analysis is managed through a three-step investigation. The first step focuses on the 'functions' presented in these web sites by categorizing the interactive tools and services provided. The second step is based on the investigation of the 'content' of these sites. Departing from the idea that content and rhetoric in online 
nationalist websites are tightly bound to each other within a mutual context, we designed the content analysis with reference to the variables derived from the previous studies in the literature on online nationalist content and rhetoric. Eight variables are employed in the content analysis: educational narrative (pedantism), historicism and tradition, use of dominant myths and symbols with constant repetition, verbal fetishization of martyrdom, de-legitimization and exclusion of other discourses by a discourse of superiority, factualization, collective subjectivity and marketing rhetoric. The analysis in the second step is based on the correlation of the variables chosen for categorizing the content and functions.

The third and last step of the analysis focuses on the design of the visual layout of these web sites. This step includes the investigation of the design aspects which have an impact on the presentation of the content through the use of specific tools.

Variables for Content Analysis:

1- Educational Narrative (Pedantism) is formulated mainly for those willing to be recruited, who are already followers and who need constant reminders from a paternalistic, authoritative, but kind voice.

2- Historicism and Tradition include references to the history of the nation and its traditions, folk etymologies, word derivations, most either fabricated or distorted.

3- Factualization signifies phrasing of a subjective perception unknown or non-agreed on item in such a way that it seems to have been already established (Thiesmeyer, 1999: 123).

4- Use of dominant myths and symbols with constant repetition.

5- De-legitimization and exclusion of other discourses by a discourse of superiority.

6- Verbal fetishization of martyrdom includes poems, songs, videos, etc. dedicated to martyrs.

7- Collective subjectivity involves the use of a virtual community to create an illusion of the real community.

8- Marketing rhetoric contains not only merchandise sales or fundraising but also tools for the promotion of propaganda and recruitment.

\section{Sampling and Analyzing Methods}

Our research attempts to provide a qualitative discursive analysis of Turkish nationalist web sites through the main features they present. A total of 118 web sites were included in the analysis. Our study was limited to web sites that are designed and moderated by nationalist groups belonging to the host nation. In other words, only web sites designed by Turkish nationalists with a Turkey-centered content are included in this study. Thus, diasporic web sites, which also reveal significant nationalistic discourse, are excluded. Three different strategies were employed for selecting the web sites. First, following a regular Google search on specific keywords on Turkish nationalism, all the web sites presented in the first 10 SERP (search engine results page) were included in the study.

The second strategy can be called as a sort of "snowball technique" (Caiani and Parenti, 2009). First, the important nationalist organizations in the Turkish network were identified. Then, the web sites of their local nationalistic units were accessed by focusing exclusively on friends links that were explicitly indicated by these organizations. The process was repeated up to the point where it became impossible to add new sites or organizations to our sample. 
The third strategy for determining the web sites included in the study were those that analyzed the traffic among sites with a common theme. Thus the particular web sites that provided a list of popular Turkish nationalistic web sites with traffic statistics were utilized. All three strategies led to the same addresses, making up of a total of 118 web sites. They enabled us to get a panoramic view of the Turkish nationalistic network structure on the web (see Appendix for their names). It can be said that the total of the samples in this study includes all the major actors in the scene of Turkish cybernationalism as well as many minor ones.

\section{RESULTS AND DISCUSSION}

The discussion will be oriented through the analysis framework, and the findings will be evaluated in two sub-sections. The first section of the analysis framework includes the network analysis of Turkish cyber-nationalism and a proposition of a concrete typology. Referring to the proposed typology, the second section comprises a three-step discussion on nationalist websites. In this section, first, we will make a brief analysis of the services. The second step will include the correlated analysis of the content and functions of the web sites. Finally in the third step, findings on the design aspects of the layout will be discussed with regard to their role in presenting a specific content through particular tools.

\section{Network Structure and Typology of Turkish Cyber-Nationalism}

Although the Internet is a place where national identities can be manipulated anew, it is not totally different from its non-virtual manifestations. As Diamandaki (2003) argues, in most cases nationalist online communities function as spaces for the re-articulation of the same "social dialogues" that usually preexist in the offline world. Accordingly, it would not be wrong to suggest that the Turkish cybernationalism is a reflection of Turkish nationalism in the political sphere. The Turkish cyber-nationalism is also as diverse as the offline Turkish nationalism. They both offer a synonymous picture. Tanıl Bora (2003; English translation by Linda Stark) proposes a classification of Turkish offline nationalism: (1) official Kemalist nationalism, (2) left-wing Kemalist nationalism, (3) liberal neo-nationalism (i.e. using the language of pro-western nationalism advocating 'civilizationism' and prosperity), and (4) Turkish radical nationalism (with the language of racist/ethnicist Turkish nationalism). Certainly, there are coinciding points between the online and offline Turkish nationalisms and it should be noted that the reflections of mainstream features of offline nationalism, such as the nationalist political parties and their ideological stances and the extremist political groups and their discourses, are largely present on the net. As an example, the two mainstream nationalist political parties (MHP and $B B P$ ) have a dominant position both in offline and online nationalisms with 89 of the 118 web sites being directly or non-officially related to these two parties. However, the organization, the extent and the variety of Turkish nationalism on the Internet appear to be quite different from offline nationalism and seem to have their own particularities. In order to better capture the distinguishing features we propose a typology of online nationalism under four categories.

1- Right-wing nationalist web sites with a party or political movement affiliation

a- Official party web sites: There are two main nationalist political parties in Turkey; one is the Nationalist Movement Party (Milliyetçi Hareket Partisi, MHP), and the other (more extremist in nature) is the Big Unity Party (Büyük Birlik Partisi, BBP). Both official web sites are included in our sample. 
b- Sites affiliated to a political party (openly or covertly): This sub-category includes web sites of groups that are the local affiliations of these two political parties, respectively Ülkü Ocakları for MHP and Alperen Ocakları for BBP. In addition, some web sites that are not openly affiliated to one of these two parties as their local branches but are affiliated informally with the movement that they represent, namely the Bozkurt or Ülkücü Movement for MHP and the Alperen Movement for BBP, and are also categorized here.

c- Sites of sympathizers of a particular political party or movement.

2- Historicist (Turanist) Nationalists: This category includes web sites that support the Turanism ideology which puts a strong emphasis on pre-Islamic Turkish traditions and history, and claims the unification of all Turkic nations and populations. Because of their emphasis on Turkish ancient history, they are labeled as 'Historicist' or 'Turanist' nationalists.

3- Neo-Kemalist Leftist (Ulusal Sol) Nationalists: Although they position themselves at the orthodox left of the political spectrum, given their rhetoric they seem to be the most racist group on the Turkish cyber-nationalist arena. They claim themselves to be the real owners of the Kemalist ideology and nationalist left, and label themselves as Ulusal Sol. Therefore, the ideology of this group will be referred in italic as the Ulusal Sol movement.

4- Nationalistic 'Forum' sites: Openly racist web sites or hate sites which are mostly designed and published by personal initiatives are excluded because they are not much present or easily found on the net, and when found they are either banned or cracked. Thus, we do not build a separate category of racist web sites. However, most exclusive and explicit racist proponents are mainly present in forum sites where unanimity and lack of control make it attractive and easy to post racist ideas.

\section{Analysis of Turkish Nationalist Websites}

Functions: Turkish nationalist web sites provide various web services and tools which can be categorized by several topics. Those 'web sites with a party affiliation,' 'forum web sites' and 'historicist web sites' are the ones employing most of the functions investigated in this study. Mostly based on a oneway interaction, neo-Kemalist leftist web sites provide the weakest function spectrum. Those leftist nationalist groups sanction one-way interaction. This particularity also reflects their offline ideology which shows more authoritarian tendencies than the other categories studied regarding the issues of human rights and freedoms.

Based on member subscription, all categories of nationalist web sites provide virtual interaction tools like a message board, a forum and even instant messaging. However, rather than deliberation, these tools serve to promote and disseminate propaganda. But to a certain extent, it can be stated that considerable effort is made by Turkish nationalist web sites to create cyber-communities of debate. However, it is also noteworthy that these groups still face some difficulties in exploiting all available multimedia tools to support interactivity. In other words, spaces of asynchronous discussion are more widely used than spaces of synchronous discussions, such as instant messaging.

Some web sites present the opportunity for users to post articles and comment. One of the major functions of nationalist web sites seems to be providing news services which make reference to media coverage on topics such as politics and the Turkish and Islamic world. Users can post comments on the news, and most of the web sites categorize the news by referring to user comments as 'most read,' 'most commented,' 'recently commented,' etc. in order to provoke further discussion. Most of the web sites share user statistics in order to contribute to user interaction. Besides the news services, the use 
of information links seems to be another dominant feature of nationalist web sites. In particular, 'web sites with a party affiliation,' 'forum web sites,' and 'historicist web sites' are overwhelmed by this function. Presented in various formats such as text, audio and video; historical information on Turkish history, traditions, Turk-Islam relationship and the Bozkurt movement were found to be popular issues in those informative links. Iconic figures such as Atatürk, Türkeş, Nihal Atsız and martyrs of the Turkish nationalists are the other features that are repeatedly mentioned in the information links.

Table 1

\section{Correlated Analysis on the Content and Functions Presented in the Websites}

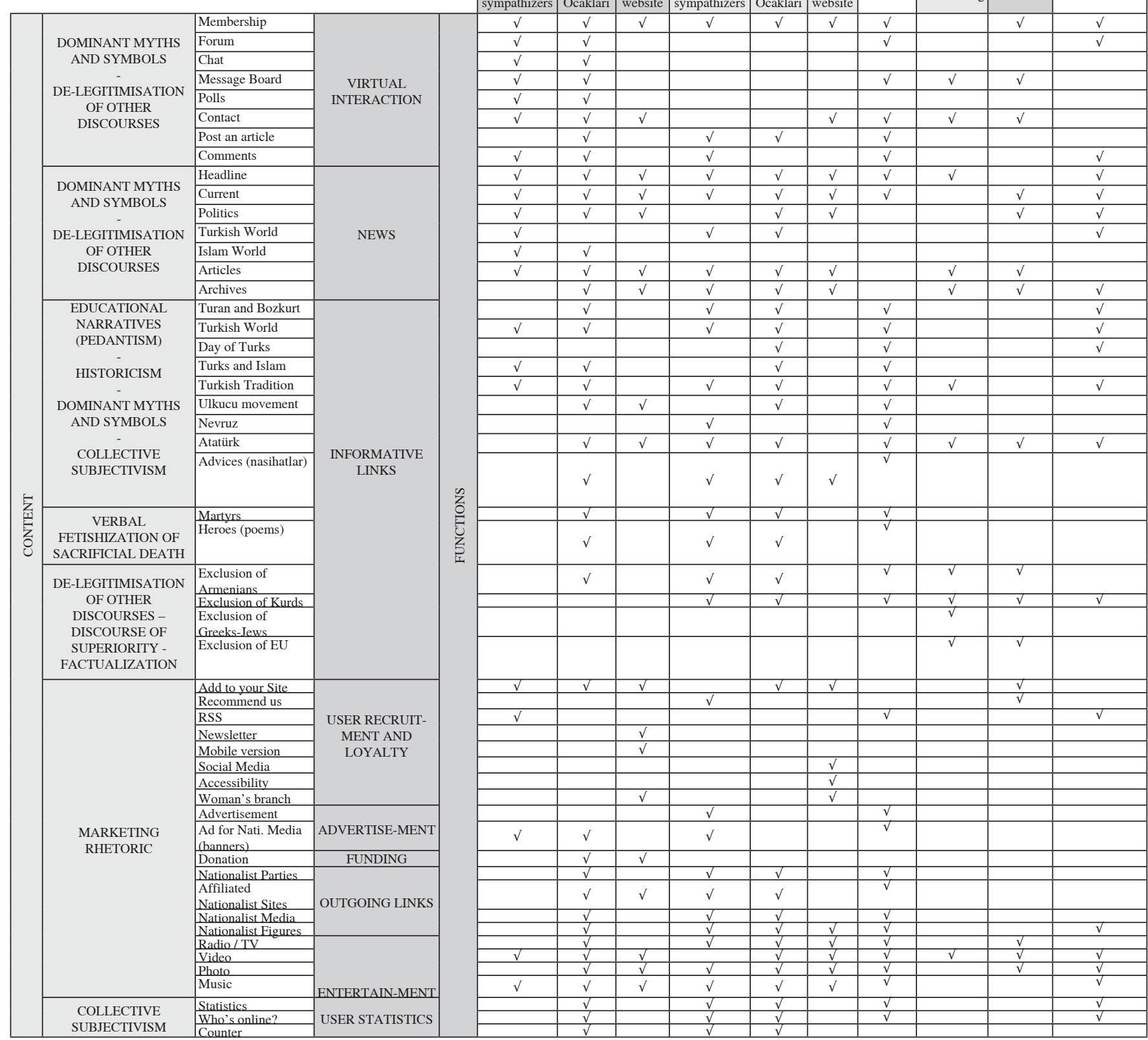


Turkish nationalist web sites also employ entertainment links like radio, TV, videos, photo gallery and music. A few of the web sites rely solely on user-generated content and it is even possible to find a site that imitates youtube (e.g. ulkucutube). Most of the web sites value user feedback and also provide user support through functions like RSS, site map, search engine, and shortcut links. Nearly all categories have banners that are embedded in the layout. However, rather than commercial motives, these banners are mainly used for promoting the current political campaigns of the organizations that they are formally or informally affiliated with. For example, supporters of the nationalistic movement (Bozkurt movement) put banners about the campaigns of the Nationalist Movement Party (MHP) on their sites. In this sense, friendly links are another dominant feature providing outgoing links to web sites that share similar political perspectives.

Content: The content will be discussed in correlation to the functions through which they are provided. The correlated analysis on content and functions proposed in each web site can be found in Table 1 . The discussion will refer to the variables mentioned earlier.

1) Educational Narratives (Pedantism): As can be seen in Table 1, most of the categories belonging to nationalist web sites place educational narratives in the information links. This finding overlaps with the recent study of Caiani and Parenti (2009: 280) which points out the usage of the web by Italian extreme-right organizations for the collection and dissemination of information.

Adopting a pedagogical approach, the analyzed web sites define their target audience either as users that demand political education or as those who need guidance from a superior authority. This informative material consists of documents that refer to a broad range of issues. The category is composed of narratives on the history of the Turkish nation, race, language and tradition, political manifestos and doctrines of the major nationalist groups, biographies and finally narratives on the iconic figures of Turkish nationalism such as Nihal Atsız, Alpaslan Türkeş and Atatürk. Alparslan Türkeş is widely used in the web sites that belong to the gray wolf (bozkurt or ülkücü) movement whereas Nihal Atsiz is the theorist of the Turanist approach which is based on pre-Islamic Turkish customs and beliefs dating back to the Göktürk period. Atatürk is adopted by both movements, but significantly he appears as a highly idealized figure -"the one and only" for the neo-Kemalist leftists. Neo-Kemalist leftists do not refer to any other national iconic figures; however, they sometimes use non-Turkish heroic figures of the revolutionary left such as Che Guevara.

It should be noted that the formats of these educational narratives represent a variety. Most of the narratives are written in the form of formal articles. However, it is also possible to observe other types such as poems, audio speeches, documentaries and even those more informal like letters to a young nationalist (ülkü̈ü) or advice (nasihatlar) which reflect a tone of paternalistic kindness. In addition, it should be emphasized that the web sites of the two nationalist political parties (MHP and $B B P$ ) show great efforts to distinguish themselves from non-party organizations and their discourses. Therefore, especially the Nationalist Movement Party $(M H P)$ (being currently the third biggest group in the Turkish parliament and the second opposition party) does not, strategically and because of its concern about its reputation, place on its official web site overtly propagandist or openly nationalist claims. They do not even provide links to their local party affiliations the Ülkü ocaklar which had a poor reputation in the past because of their part in violent manifestations and criminal cases.

The various web sites of the Big Unity Party $(B B P)$ in their turn also pay attention to this issue on the official web site; however, they behave more like militants of nationalist ideology and prefer to 
provide links to their local affiliation of the Alperen ocaklart that shares almost the same problems of reputation as the Ülkü ocaklarl. It would be correct to assume that especially the $M H P$ is doing what Gerstenfeld et al. (2003: 40) call "image control" which aims to make the web site and its owner more credible and respectable through a slick, professionally-looking design, and carefully chosen words.

2) Historicism and tradition: As mentioned in the discussion on the first category, educational narratives mostly rely on historicism and tradition. In particular, the narratives on the history of the Turkish nation, race, and language through the Turanism ideal become prominent in this category. Turanism, which is an over-whelming theme in the historicist web sites, envisions the unification of all Turkic geographies and ethnicities under one common rule. This ideal is supported by historical texts referring to symbols like Gök Tengri, which belong to the pre-Islamic Turkish period. Although the turanism ideal can be evaluated as a motto for only one single category of Turkish nationalists, namely turanists (or historicists), other categories also seem to value it. Turanist ideals addressing Turkish unity are one of the fundamental tools employed in the reconstruction of nationalist discourses of both the Ülkücü movement and the Alperen movement which represent the majority of the Turkish nationalism sites.

Historicist rhetoric also exposes a variety of forms. It is presented mostly as historical narratives with an epic tone. Repetitive references to Turkish traditions (töre), folk etymologies and even word derivations based on a pre-Islamic Orkun language (Abaca) are also frequently used. A significant example of the latter is one of the web sites which provided a dictionary for original Turkish names based on the Orkun language (hunturk.net).

3) Use of dominant myths and symbols with constant repetition: All categories of the nationalist web sites make extensive use of dominant myths and primary symbols repeated constantly through the virtual interaction, and news tools and information links. Discussions in forums, news chosen from media coverage and informative material in the relevant links are all accompanied by symbols of Turkish nationalism. These web sites reveal an ample anthology of documents, photos and propaganda material recalling Turkish nationalistic iconography and rhetoric. These symbols serve as the historical and cultural glue of the national identity and contribute to the unification of offline nationalist communities on the web. However, the opposite is also possible here. The use of these symbols also enables the emergence of new communities that cannot be easily observed or maintained in the current offline political spectrum. While in the actual physical political spectrum individuals do not have a chance to articulate and gather to support allegiance to the customs of the pre-Islamic Turkish period, virtual space provides them with this opportunity to realize this ideal of Turanism. In the offline political world there are limits stemming from the political culture and socio-political context of the respective country that draws the line between possible and impossible and between feasible and nonfeasible. Therefore, some movements in Turkey remain so marginal that their existence is not easily perceivable in the political scene.

The wolf, the Turkish flag, the flags of the Turkic republics in Asia, collections of epic tales and legends about the glorious events of the past, the Göktürk alphabet, metaphors (ota $\breve{g}$ ) and cognomens addressing Turkish history (soydaş, ırkdaş, kandaş, ülküdaş) and photographs of Nihal Atsız, Alparslan Türkeş and Atatürk can be cited as the most popular symbols. Furthermore, those people are praised as quasi-divine personalities whose quotations glorifying the supremacy of the Turkish race and nation are popping up in almost every web site. Heroism and martyrdom are also found to be popular symbols which are discussed below as a separate category. 
4) Verbal fetishization of martyrdom: The content in this category is based on the persistent emphasis on national pride that emanates from heroism and a glorification of martyrdom. Both concepts involve emphases on legends and accomplishments of nationalists who fought till death for the glory of Turkish nationalism. The martyrs of the Turkish army in the war with the PKK (Partiya Karkerên Kurdistan - Kurdistan Labor Party) are also recurring symbols. There are even specific web sites devoted to the memory of martyrs and forum web sites that serve as a communication platform for the families of martyrs. In all web sites, the Turkish army is glorified to the extent that each Turk should surrender himself to the sacredness of the army. The Turkish militarist culture, paraphrased as "each Turk is a natural born soldier," is reflected on these web sites because military service and martyrdom constitute the most essential duties as well as the highest level of glory of a citizen. At the same time, it is a 'natural' indicator of Turkishness. However, constructing Turkish identity by emphasizing the warrior nature of Turks often results in a tendency to adopt violent attitudes and measures in current domestic and foreign policy. The consequences of this tendency, particularly in the discussion forums, lead to hate messages against the minorities and ethnicities that become increasingly difficult to mitigate.

5) De-legitimisation and exclusion of other discourses: De-legitimisation and exclusion of the discourses of ethnicities living in Turkey is found to be a fundamental content category in nationalist web sites. In this sense, two complementary tendencies of racist or ethnicist discourse appear. The first one praises the superiority of the Turkish nation while the second one openly humiliates other ethnicities, particularly Kurds, Armenians, Greeks and Jews. In the neo-Kemalist leftist web sites in particular, this content category is generated from issues concerning Turkish foreign policy. According to these nationalistic sites, the main direction of Turkish foreign policy should include a detachment from the influence of the US which is seen as the main financer of PKK terror, and that of the EU which has a secret agenda for the partition of Turkey. Moreover, the EU membership is strongly rejected on the grounds that it will cost Turkey the loss of Cyprus. In these forums, Russia also receives many criticisms as the persecutor of Turkic people.

At the function level, this de-legitimization approach is made significantly explicit in discussion forums that can be found either as integrated features in web sites or as separate sites. These forums play an important role in the construction of the collective identity of the group by defining who the 'enemies' and the 'allies' are and what the main goals of the group are (Caiani and Parenti, 2009). Provocative discussion topics on conflicts with other ethnicities (e.g. Armenian genocide, PKK terrorism) posted by the moderators provide a basis for users to express hatred against other discourses in an overt and offensive tone. On the other hand, although the adopted rhetoric is defined by a more subtle tone based on coded metaphors, news presented in these web sites also contributes to this approach. Either the news chosen from media coverage or the news posted by the moderator and users presents a subtext of hatred with a mantle of value-neutral rhetoric.

De-legitimisation and exclusion of other discourses can also be traced in informative links which are used for political education and enlightenment. A huge number of articles and dossiers claiming to shed light on the conflicts with Armenians and Kurds are widely distributed through these links. Besides articles on the "Armenian Reality" and the "Kurdish Problem;" conspiracy theories on other issues such as "Missionary Ideals of Greeks," "Mutual Relations between the Governing Justice and Development Party and the Nûr Creed" and even "Secret Collaborations between the Jews and the USA" are also implied. These kinds of conspiracy theories can be evaluated under the category of factualization as well which tends to show, with evidence from invented facts, a collapsed offline world order full of conspiracy scenarios and threats to the nation as an already recognized phenomenon. The 
discourse, embedded in informative material, is a major feature in the neo-leftist web sites, namely the 'turksolu' (Turkish left). Though the name recalls a left-leaning point of view, the "turksolu" web site is the platform which adopts the most polarized and blatantly racist discourse among them. The Kurds constitute the principal target of the bloggers of these nationalist environments even though these web sites also generate hate messages through articles against Armenians and Islamic groups as well. Articles on the "Invasion Plan of the Kurds" are supported with maps and statistics. The authors feel free to speak openly about the exclusion of Kurdish people in daily social life and to advise Turkish people to avoid shopping from Kurdish stores, listening to Kurdish music, eating Kurdish food and marrying a Kurdish person.

The characteristic tone and message of this discourse is that of alarm. Through a tone of paternalistic kindness, this so-called informative material claims that the audience, who is completely unaware of the facts, has been used and manipulated without its knowledge. This finding corresponds to the work of Thiesmeyer on racism on the web. Thiesmeyer (1999: 121) asserts that this strategy is probably the easiest way to alarm the audience, as anything that has happened without their knowledge is a phenomenon that does not require much evidence: it is all happening behind the scene and is thus more frightening. She states that "the website itself is seen as evidence of the argument it propounds." It is obvious that this approach is open to the fabrication or distortion of the facts which can easily be embedded in long and dense textual materials.

6) Factualization: The findings support the notion that educational narratives in informative links, which reveal a discourse based on the exclusion of other discourses, benefit from factualization. Arguments, which are gathered in an eclectic way, are authoritatively represented with serious assertions but without empirical proofs. This anonymous material composed of long pages of texts is targeted towards people who browse the net quickly and presumably without time and interest for any background debate on what might have produced the so-called fact. Referring to Thiesmeyer (1999: 124), it can be stated that factualization here lends itself to persuasion and recruitment of web text readers who want to surf it using the minimum of time for careful reading.

7) Collective subjectivity: Collective subjectivity can be defined as "the use of virtual community to create an illusion of real community" (Thiesmeyer 1999: 122). Especially in mainstream Turkish nationalist web sites, collective subjectivity can be traced in informative links on Turanism, which relies on the vision of the unification of all Turkic populations. Extensive emphasis on Turkish union with a constant repetition implies the existence of numerically significant groups behind both the web site and the ideal itself, and plays a crucial role in conveying a message containing the group's ideology.

Tools that provide user statistics such as 'who's online' links and hit counters are used to support the establishment of the illusion of collective subjectivity. Nationalist groups seem to be willing to show the popularity of their web sites to the audience. However, it is obvious that the user statistics can be artificially manipulated by the moderators in order to support the illusion of the existence of a huge virtual community sharing common nationalistic ideals (for an example see Gerstenfeld et al., 2003: 40). Therefore, it should be noted that the real organizational strength behind a web site is always difficult to estimate, and, in that sense, open to manipulation.

8) Marketing Rhetoric: Several studies underline that throughout the world right-wing extremists are increasingly using the Internet as a tool for facilitating recruitment, reaching a global audience 
and connecting with other groups (e.g. Lee and Leets, 2002; Tateo, 2005; in Caiani and Parenti, 2009: 274). Thiesmeyer (1999) also asserts that recruitment and marketing success of the nationalist groups have a great deal to do with the ability of the web to transcend national boundaries for linking enormous numbers of people.

Our findings on Turkish nationalist web sites seem to be in line with the relevant literature. Firstly, the illusion of collective subjectivity seems to play an important role in recruitment. It indicates the so-called feeling of security within a solid community and enables the dissemination of propaganda for the recruitment of new followers. Outgoing links and banners for the well-known nationalist media and for other nationalist organizations also support this strategy by addressing a greater traffic. User recruitment is enabled by tools of viral marketing like 'recommend us' and 'add to your site' whereas user loyalty is supported with mobile versions of the websites and RSS technology, which is one of the new tools of the Web 2.0 paradigm. Web sites of the Alperen movement, which is a sub-group of one of the major nationalist political parties $(B B P)$, even employs donation tools for funding.

The majority of the sites also use entertainment links which serve as multimedia content for user recruitment. The multimedia approach allowed by the web is particularly appealing to young people who usually are the preferred target of the extremist groups' recruitment (Gerstenfeld et al., 2003: 38; in Caiani and Parenti, 2009: 282). It is obvious that due to its low cost, a new form of propaganda has emerged. Nationalist groups can dictate their rhetoric, update their discourse on daily basis, and reach millions of users for a much lower price than they once would have spent for publicity.

\section{Visual Design of the Layout}

The importance of design has been recognized widely in the online community literature for, as Preece (2001: 349 in Wright and Street 2007: 854) puts it, "designing for usability is not enough; we need to understand how technology can support social interaction and design for sociability." In this context, Wright and Street (2007) argue that what will determine the nature of participation through the Internet is not only the content of discussion in forums but also how these sites are designed and the discussions are organized.

Despite the fact that Turkish nationalist web sites offered tools for user interaction and support, an in-depth analysis of the visual layouts of the forum sites indicates the reconstruction of an oriented and manipulated interaction. Though this finding demands verification through further interviews with the designers of these sites, the layouts of the majority of the forum web sites revealing similar visual aspects seem to support our assertion. Just like the nationalist web sites in other categories, most of the forum sites also have homepages overwhelmed by the use of well-known symbols of Turkish nationalism mentioned in previous sections. All discussion topics which are based on an offensive and racist discourse are given as a list and are located in the middle of the page layout that is decorated with nationalist symbols. The visitors can quickly have a look at the discussion topics and easily navigate towards the chosen topic. Besides using the list of discussion topics or categories, access to the forums is also supported with search and help tools. "Ulkucuderlerbize.com," which is one of the most popular nationalist forum sites with a high traffic, can be given as a typical example. 
Picture 1

Visual Layout of a Nationalist Forum Site Decorated with Nationalist Symbols

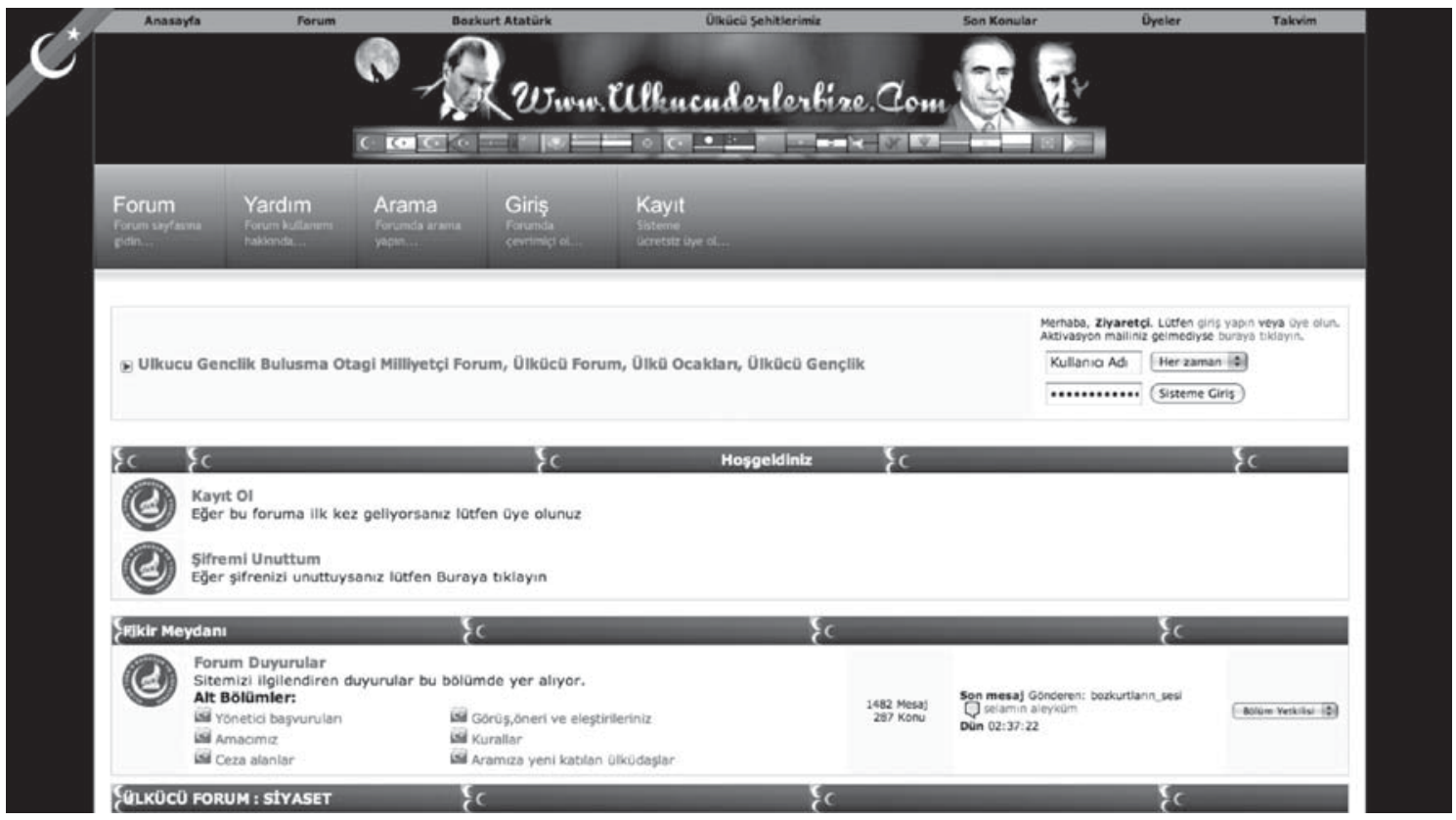

According to Horton (2008), good design depends on creating a hierarchy of contrast and viewer attention, so that a few focal areas of the page become entry points and the other page materials are clearly secondary. Our analysis showed that tools like manageable headline areas were used as primary visual entry points in most of the sites. However, the intention does not seem to be to provide a consistent user experience, but rather to promote certain ideas through the visual entry points in the layout. As a typical example, the news headline bar in the "gok-turkler.net" is located at the middle of the homepage as a visual entry point big enough to be unavoidable (Picture 2).

Picture 2

Use of News Headline Bar to Promote Propaganda

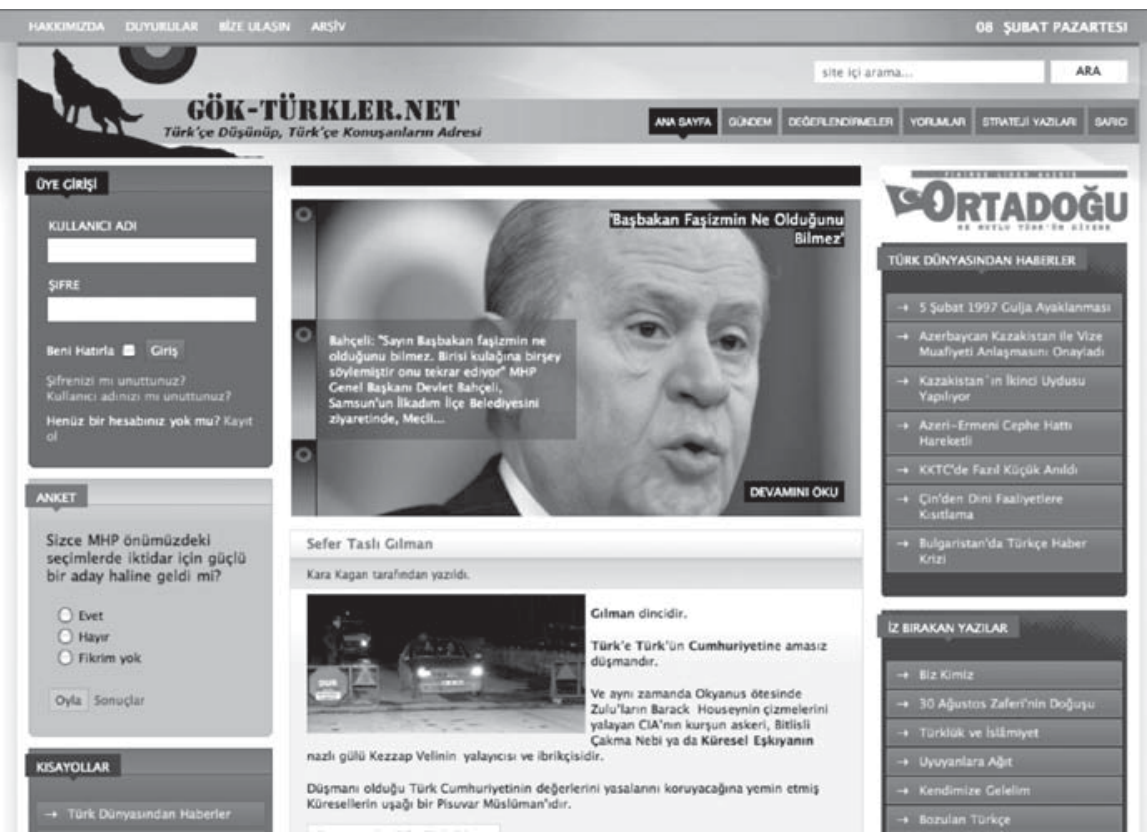


This headline area includes three different news items that flow in a loop. However, at least one of three items is about the Nationalist Movement Party and is accompanied by the photo of its political leader. The remaining items are chosen from the ones that favor the movement's ideology and contribute to its discourse by criticizing its adversaries

\section{CONCLUSION}

The Internet is a strong tool which might help us reconfirm our identities; but it may also lead us to think critically and dispute their very foundations (Diamandaki, 2003). Our study investigates the network structure of Turkish nationalism and proposes a concrete typology. It concludes that Turkish nationalists mainly use the Internet in order to diffuse their ideology, to strengthen Turkish national identity and the nationalist community structure and finally to build a dedicated virtual community. In order to realize these purposes, Turkish nationalists benefit from various content categories. Educational narratives based on historicism and dominant symbols support the reproduction of nationalist values and strengthen national allegiances. Factualization embedded in educational narratives enables the delegitimization of other discourses and constitutes the most significant category in the findings. Mostly presented through the tools of virtual interaction, news items and informative links, this category reveals two distinctive discourses, one emphasizing the greatness of the Turkish nation and the other excluding the presumed 'Others' (mostly Kurd and, Armenians) and threats coming from supposed enemies (mostly the U.S.A, the EU, Kurds, and Islamists). Collective subjectivism is mostly employed for building a virtual community of new followers and for supporting the current community structure. At this point, in order to recruit new followers or to provide fundraising, new web technologies of marketing are used effectively and exclusively. Findings also reveal that the visual layouts of the web sites provide opportunities for the reconstruction of an oriented and manipulated interaction organized around the imposed nationalist ideology.

Regarding the particular relation between the Internet and nationalism, it might be considered too hasty to argue definitely that the Internet serves to strengthen nationalist ideologies and allegiances rather than merely reproducing them on a new virtual area. Such questions as "do the sites, in fact, 'convert' new extremists, or do they simply inform and unify existing ones?" (Gerstenfiled et al., 2003) are crucial. It can only be answered by inspecting the interaction between these sites and their users. Therefore, looking more closely at the user side is a must for a future research agenda in order to fully capture the picture. Nevertheless, with the already available data, either specifically from this study or generally from the relevant literature, it is quite possible to conclude that the Internet plays a significant role in the (re)production of nationalism through new tools that are easy to manipulate and widely diffuse. Thus, it is extensively and also professionally used by nationalists or other types of extremist groups in order to spread their messages and ideologies as well as their hate - openly or covertly - against their presumed 'Others.'

As Kluver points out, the technological optimism - which sees in the Internet the end of nationalism and parochialism - is grounded "not only in a romantic understanding of human motivation, but also an unrealistic understanding of how the Internet functions as a medium for human interaction" (2001: 8). As claimed by Wright and Street, "technology can facilitate deliberation but cannot guarantee that it will happen in any one particular way" (2007: 8). Time will show us which side of the Internet either its deliberative or dark side - will triumph in this virtual/visual battle. However, further research, especially including the user side as well, is undoubtedly necessary to be able to better analyze the real extent of the dark side of Internet and the conditions under which this latter comes into being in order 
to predict to which future this virtual Internet battle between deliberation and hate, between more democracy and more nationalist separatism will lead us.

\section{REFERENCES}

Anderson, B. (1983). Imagined Communities: Reflections on the Origin and Spread of Nationalism. London: Verso.

Anderson, D.M. and Cornfield, M. (eds.) (2003). The Civic Web: Online Politics and Democratic Values. Lanham, MD: Rowman and Littlefield.

Anyefru, E. (2008). "Cyber-Nationalism: The Imagined Anglophone Cameroon Community in Cyberspace," African Identities. 6(3): 253-274.

Bakker, P. (2001). “The Internet Crusade; New Nationalism.” Paper prepared for the 2001 International Studies Association Annual Convention 'International Relations and the New Inequality: Power, Wealth, and the Transformation of Global Society at the Beginning of the Twenty-First Century.' Chicago. 20-24 February 2001.

Barnett, B.A. (2007). "Hate Group Community-Building Online: A Case Study in the Visual Content of Internet Hate Sites.” Proceedings of the New York State Communication Association, 2007.

Bora, T. (2003). "Nationalist Discourses in Turkey," (Translation by Linda Stark), South Atlantic Quarterly, 102: 433-451.

Burris, V., Smith, E., and Strahm, A. (2000). "White Supremacist Network on the Internet," Sociological Focus, 33: 215-234.

Caiani, M. and Parenti, L. (2009). "The Dark Side of the Web: Italian Right-Wing Extremist Groups and the Internet," South European Society and Politics, 14(3): 273-294.

Caiani, M. and Wigemann, C. (2009). "Online Networks of the Italian and German Extreme Right;" Information, Communication and Society; 12(1): 66-109.

Canefe, N. (2002). "Turkish Nationalism and Ethno-Symbolic Analysis: The Rules of Exception," Nations and Nationalisms. 8(2): 133-155.

Chan, B. (2005). "Imagining the Homeland: The Internet and Diasporic Discourse of Nationalism," Journal of Communication Inquiry. 29(4): 336-368.

Curtis, A. (2005). "Nationalism in the Diaspora: A Study of the Kurdish Movement," Nationalism, Ethnicity and Conflict, Available [on line] at: http://www.learnignorance.com/Un/Papers/Curtis-Kurdish-Diaspora.pdf

Dalhgren, P. (2000). “The Internet and the Democratization of Civic Culture," Political Communication. 17: 335-340. 
Dalhgren, P. (2005). “The Internet, Public Sphere and Political Communication: Dispersion and Deliberation," Political Communication, 22: 147-162.

Diamandaki, K. (2003). "Virtual Ethnicity and Digital Diaspora: Identity Construction in Cyberspace," Global Media Journal, 2(2): Available [on line] at: http://lass.calumet.purdue.edu/cca/gmj/ OldSiteBackup/SubmittedDocuments/archivedpapers/spring2003/diamondaki.htm

Donelan, B. (2004). "Extremist Groups of the Midwest: A Content Analysis of Internet Websites," Great Plains Sociologist, 16(1): 1-27.

Eriksen, T.H. (2007). “Nationalism and the Internet,” Nations and Nationalism, 13(1): 1-17.

Gerstenfeld, P., Grant, D.R., and Chiang, C. (2003). "Hate Online: A Content Analysis of Extremist Internet Sites," Analyses of Social Issues and Public Policy, 3(1): 29-44

Gladney, D.C. (2005). "Cyber-Separatism and Uyghur Ethnic Nationalism in China," Available [on line] at: http://www2.hawaii.edu/ dru/articles/cyberseparatism.pdf

Glaser, J., Dixit, J, and Green, D.P. (2002). "Studying Hate Crime with the Internet: What Makes Racists Advocate Racial Violence?” Journal of Social Issues. 58(1): 177-193.

Gol, A. (2005). "Imagining the Turkish Nation through 'Othering' Armenians," Nations and Nationalisms, 11(1): 121-139.

Güngör, M. (2007). Nationalism on the Internet: The Role of Greek 'Others' in the Formation of Turkish Nationalism. Master's Thesis, Graduate School of Arts and Sciences of Georgetown University. April 2007.

Hoffman, S. (1996). The Web of Hate: Extremists Exploit the Internet. New York: Anti Defamation League.

Horton, S. (2008). Web Style Guide, 3rd Edition. Available [on line] at: http://webstyleguide.com/wsg3/index.html

Keyman, E.F. and Kanc1, T. (2011). “A Tale of Ambiguity: Citizenship, Nationalism and Democracy in Turkey," Nations and Nationalisms, 17(2): 318-336.

Kluver, A.R. (2001). "New Media and the End of Nationalism: China and the US in a War of Words," Mots Pluriels. No.18. August 2001. Available [on line] at: http://www.arts.uwa.edu.au/MotsPluriels/MP1801ak.html

Lee, E. and Leets, L. (2002). "Persuasive Storytelling by Hate Groups Online: Examining its Effects on Adolescents," American Behavioral Scientist, 45: 927-957.

Liu, S. (2006). "China's Popular Nationalism on the Internet. Report on the 2005 Anti-Japan Network Struggles,” Inter-Asia Cultural Studies, 7(1):144-155. 
McLelland, M. (2008). “'Race' on the Japanese Internet: Discussing Korea and Koreans on 2-Channeru," New Media and Society, 10(6): 811-829.

Miller, D. and Slater, D. (2000). The Internet: An Ethnographic Approach. Oxford: Berg.

Parker, D. and Song, M. (2006). "New Ethnicities Online: Reflexive Racialisation and the Internet," The Sociological Review. 54(3): 575-94.

Preece, J. (2001). "Sociability and Usability in Online Communities: Determining and Measuring Success," Behaviour and Information Technology, 20(5):347-356.

Quintelier, E. and Vissers, S. (2008). "The Effect of Internet Use on Political Participation: An Analysis of Survey Results for 16-years-olds in Belgium," Social Science Computer Review. Published online on February 5, 2008.

Rajagopal, I. and Bojin, N. (2002). "Digital Representation: Racism on the World Wide Web," First Monday, 7(10). Available [on line] at:

http://firstmonday.org/htbin/cgiwrap/bin/ojs/index.php/fm/article/viewArticle/995/figure1.html

Rizvanoğlu, K. and Güney, S. (2009). "Recreation of the Homeland in Cyberspace: A Case Study on Diasporic Web Sites." Paper presented at II. International Congress of European Turks in Antwerp. 14-16 May 2009.

Shanadi, G. (2007). "Right-Wing Hindu Nationalism on the World Wide Web: An Analysis of HinduUnity.org" Global Media Journal, 6 (10): Available [on line] at:

http://lass.calumet.purdue.edu/cca/gmj/sp07/graduate/gmj-sp07-grad-shanadi.htm

Smith, A.D. (1986), The Ethnic Origins of Nations. Oxford: Blackwell.

Tambini, D. (1999). "New Media and Democracy: The Civic Networking Movement," New Media and Society, 1(3): 305-329.

Tateo, L. (2005). "The Italian Extreme Right On-line Network: An Explanatory Study Using an Integrated Social Network Analysis and Content Analysis Approach," Journal of omputer-Mediated Communication, 10 (2). article 10. Available [on line] at :

http://jcmc.indiana.edu/vol10/issue2/tateo.html

Thiesmeyer, L. (1999). "Racism on the Web: Its Rhetoric and Marketing," Ethics and Information Technology, 1: 117-125.

Tian, R.G. and Wu, Y. (2007). "Crafting Self-Identity in a Virtual Community: Chinese Internet Users and Their Political Sense Form," Multicultural Education and Technology Journal, 1(4): 238-258.

Uimonen, P. (2001). Transnational.Dynamics@Development.Net: Internet, Modernization and Globalization. Stockholm: Department of Social Anthropology. 2001. 
Weimann, G. (2006). "Virtual Disputes: The Use of the Internet for Terrorist Debates," Studies in Conflict and Terrorism, 29(7): 623-639.

Wright, S. and Street, J. (2007). "Democracy, Deliberation and Design: the Case of Online Discussion Forums". New Media and Society, 9(5): 849-869.

Zhou, Y., Reid, E., Qin, J., Chen, H., and Lai, G. (2005). "U.S. Domestic Extremist Groups on the Web: Link and Content Analysis," IEEE Intelligent Systems, 20(5): 44-51.

\section{APPENDIX}

\section{1- Nationalist web sites with a party or political movement affiliation (89)}

a) Official Party Websites (2)

BBP (Buyuk Birlik Partisi) (Big Unity Party) www.bbp.org.tr

MHP (Milliyetci Hareket Partisi) (Nationalist Mouvement Party) http://www.mhp.org.tr/

\section{b) Sites Affiliated to a Political Party (65)}

\section{Ulku Ocaklari of MHP (42)}

Ülkü Ocakları http://www.ulkuocaklari.org.tr/?CCC

Erenköy Ülkü Ocağı http://www.erenkoyulkuocagi.org/

Trabzon Ülkü Ocakları http://www.trabzonulkuocaklari.org/

Ülkü-Ocağ1.net http://www.ulkuocagi.net/modules.php?name=News\&file=article\&sid=1934

Aksaray Ülkü Ocakları http://www.aksarayulkuocaklari.com/site/news.php

Ankara Ülkü Ocakları http://www.ankaraulkuocaklari.net/

Bursa Ülkü Ocakları http://www.bursaulkuocaklari.net/index.php

Ankara Fatih Ülkü Ocağı http://www.fatihulkuocagi.com/

Bigadiç Ülkü Ocakları http://www.bigadiculkuocaklari.org/site/

İzmir Ülkü Ocakları http://www.izmirulkuocaklari.org/CCC/

Çubuk Ülkü Ocakları http://www.cubukulkuocaklari.net/

Bandırma Ülkü Ocakları http://bandirmaulkuocaklari.blogcu.com/

Osmaniye Ülkü Ocakları http://www.osmaniyeulkuocaklari.com/

Tokat Ülkü Ocakları http://www.osmaniyeulkuocaklari.com/

Antalya Ülkü Ocakları http://www.antalyaulkuocaklari.com/

Sivas Ülkü Ocakları http://www.sivasocak.com/

Bahçelievler Ülkü Ocakları http://www.istbahcelievlerulkuocagi.org/

Sincan Ülkü Ocakları http://www.istbahcelievlerulkuocagi.org/

Kartal Ülkü Ocakları http://www.kartalulkuocaklari.com/ocak/

Rize Ülkü Ocakları http://www.rizeulkuocaklari.net/

Esenevler Ülkü Ocakları http://esenevlerulkuocaklari.6te.net/ataturk.htm

Adana Seyhan Ülkü Ocakları http://seyhanulkuocagi.hareketforum.com/portal.htm

Geyve Ülkü Ocakları http://geyveulkuocaklari.org/weblinks.php?cat_id=2

Pendik Ülkü Ocakları http://www.pendikulkuocaklari.com/search.php

Ali Fuat Paşa Ülkü Ocağı http://alifuatpasaulkuocagi.org/?Bid=216829

Bağcılar Ülkü Ocağı http://bagcilarocak.tr.gg/ 
Çerkezköy Ülkü Ocakları http://www.cerkezkoyulkuocaklari.com/news.php

Üniversiteli Bozkurtlar_http://www.unibozkurt.com/

http://www.ulkucuhaber.com/data3/

http://www.mhphaber.com/haber_detay.asp?baslik_id=44\&ID=3850

http://www.bizimocak.net/haberler.php

http://www.mhpforum.org/showthread.php?t=359

http://www.ulkucu.org/

http://www.turkiyenindavasi.tr.gg/ana-sayfa.htm

http://malatyaliulkuculer.blogcu.com/

http://www.hedefimizturan.tr.gg/Ana-Sayfa.htm

http://www.millisimge.com/

http://www.cankayaliulkuculer.tr.cx/

http://www.ulkucuvideo.com/

http://www.UlkuTube.Com/

http://www.bozkurtyuvasi.net/forum/

http://www.yutes.net/

\section{Alperen Ocaklari of BBP (23)}

'Alperen Ocaklari' http://alperenocaklari.org.tr/index.php?option=com_frontpage\&Itemid=1

Avrupa Türk Birliği http://www.atb-europa.com/

Selçuklu Vakfı (SOGEV) http://selcukluvakfi.org/

Eğitimde Birlik Derneği http://www.ebirder.org/default.asp

Genç Alperenler http://www.gencalperen.com/

Muş Alperen Ocakları http://www.musalperenocaklari.org

Samsun Alperen Ocakları http://www.samsunalperen.com/anasayfa.php

Berlin Alperen Ocakları http://www.berlin-alperen.de/index.php

İstanbul Alperen Ocakları http://www.istanbulalperen.org/

Bakırköy Alperen Ocakları http://www.bakirkoyalperenocaklari.com/web/

Beykoz Alperen Ocakları http://www.alperenbeykoz.com/

Ümraniye Alperen Ocakları http://www.umraniyealperen.com/

Bozkır Alperen Ocakları http://www.bozkiralperenocaklari.com/

GaziOsman Paşa Alperen Ocakları http://www.gopalperen.tr.cx/

Sivas Alperen Ocakları http://www.sivasalperen.com/index.php

Kayseri Alperen Ocakları http://www.kayserialperen.com/

Şarkışla Alperen Ocakları http://www.sarkislaalperen.com/

Amasya Alperen Ocakları http://www.alperenamasya.com/list/list.asp?ktgr_id=354

Tokat Alperen Ocakları www.tokatalperen.org

Erzincan Alperen Ocakları http://www.erzincanalperen.org/ulkudevleri.asp?syf=kimler

Keçiören Alperen Ocakları http://www.keciorenalperenocaklari.org/?\&Bid=252910

Haber Hilal www.haberhilal.com

Ozan Hasan Sağındık www.hasansagindik.com.tr

c) Sites of sympathizers of a particular political party or movement (22)

Sites of sympathizers of MHP (20)

http://www.gok-turkler.net/ 
http://www.yalniz-kurt.com/

http://www.ergenekonas.tr.gg/

http://www.y-tm.com/

http://www.muhurgoslum.tr.gg/

http://www.tekbirligimiz.tr.gg/Ana-Sayfa.htm

http://www.bozkurttoresi.tr.gg/

http://www.turandanseslenis.blogspot.com/

http://www.karahilal.net/index.htm

http://www.otukenim.net/

http://www.uchilal.com/

http://www.yusufiye.net/index.php

http://www.asilkan.org/

http://www.sanalocak.org/

http://www.yalnizkurt.org/

http://www.ulkumuz.net/

http://www.ulkudebirlik.com/

http://www.turandevlet.com/

http://www.ulkuerleri.org/

http://www.millikimlik.com/

Sites of sympathizers of BBP (2)

http://www.turkdirilisi.org/

http://www.medeniyetocagi.org/wp/

2- Historicist (Turanist) Websites (3)

Hun Türkler http://hunturk.net/

Nihal Atsiz http://www.nihalatsiz.org/

Türk Ülküsü http://www.turkulkusu.com/

3- Neo-Kemalist Leftist (Ulusal Sol) Nationalists (5)

IP (İşçi Partisi) (Labor Party) http://www.ip.org.tr/

Aydınlık Dergisi http://www.aydinlik.com.tr/

Doğu Perinçek http://www.doguperincek.info/

Türk Solu http://www.turksolu.org/

http://www.vatansohbetimiz.blogspot.com/

4- Nationalistic 'Forum' sites (21)

http://www.ulkucuderlerbize.com/

http://www.ulku-ocaklari.com/index.php

http://www.turkislamdevletleri.com/

http://www.radyobayrakfm.de.tl/

http://www.bozkurtforum.org/ 
http://www.bozkurtfm.net/

http://hedefturan.he.funpic.org/forum/

http://www.turkuazcilar.net/

http://www.turkislamocagi.tr.gg/

http://www.vatankolik.com/web/

http://www.ulkucutavir.com/

http://osmanlitokadi0326.tr.gg/

http://www.ulkuotagi.com/forum/

http://tiyansan.hareketforum.com/portal.htm

http://www.bozkurtbartin74.de.tl/

http://www.ulkucu.somee.com/

http://www.simdiaskerim.com/forum/

http://www.turkiyem.org/

http://www.otagim.com/

http://www.ulkucuyuz.org/forumdisplay.php?f=53

http://www.turkobasi.com/ 